DOI: https://doi.org/10.32782/2410-0927-2020-13-10

УДК 821.112.2(436)’06-31.09Цвейг:001.8

Сорія Козак

\title{
ФРЕЙМ «ПОЧУТТЯ» В ХУДОЖНЬОМУ ДИСКУРСІ (на матеріалі творчості австрійського письменника С. Цвейга)
}

У статті здійснено аналіз фреймових структур на позначення почуттів у художньому дискурсі. Докладно розглянуто поняття «фрейм» та «фреймова структура». Фрейми кваліфіковано як когнітивні утворення, складовими частинами яких є термінали і які реалізуються в дискурсі через фреймові структури. Ключові компоненти фреймових структур - термінальні елементи, що безпосередньо пов'язані 3 мовною реалізацією терміналів. Дослідження виконано на матеріалі роману Стефана Цвейга «Ungeduld des Herzens» («Нетерпіння серця»). У цьому творі проаналізовано фреймові структури, у яких термінальні елементи, що представляють фрейм «Почуття», відображають емоційну сферу персонажів і розкривають їхній внутрішній світ. У дослідженні описано структуру фрейму «Почуття» та визначено його основні термінали. Цей фрейм розглядаємо як ментальне утворення, в основу якого покладено категоріальні знання про людські почуття - те, що люди відчувають не розумом, а внутрішньо, «в душі», наприклад страх, полегшення, радість, безпечність, невпевненість й ін. На основі словникової дефініції визначено базові термінали фрейму «Почуття» («GEFÜHL»): «Внутрішнє поривання» («seelische Regung»), «Відчуття» («Empfindung»), «Настроєність» («Einstellung»), «Ставлення до світу» («Haltung zur Welt»). У рамках цих терміналів здійснено комплексний аналіз лексичних одиниць, що зображають почуття героїв poмaну «Ungeduld des Herzens», показано різні відтінки їхніх переживань і думок, описано найпотаємніші мрії, передано найрізноманітніші поривання людської душі. Зазначені вище фреймові структури дають ключ до розуміння вчинків героїв твору та їхніх мотивів, відображають почуття, які штовхають дійових осіб на відчайдушні кроки, як на подвиги, так і на злочини; висвітлюють пристрасті, що можуть стати як причиною невдач, так і підгрунтям для зародження нових стосунків. Аналіз текстового матеріалу засвідчив, що фреймові структури на позначення емоцій і почуттів $\epsilon$ продуктивним засобом у відображенні внутрішнього світу літературних героїв та ефективним механізмом експлікації авторської прагматики.

Ключові слова: фрейм, фреймова структура, термінал, термінальний елемент, почуття, емоція.

Вступ. У сучасному світі одним з актуальних методів у галузі лінгвістики $є$ фреймовий аналіз, який стає дедалі більш популярні у мовознавчій сфері і прикладних до неї наук. Фреймові моделі виявилися доволі практичними в застосуванні, через те низка когнітивних наук, таких як когнітивна психологія, когнітивна лінгвістика, нейропсихологія та ін., використовують їх для моделювання структур, властивих людській свідомості, і визначенні, зокрема корелятивних зв’язків між когніцією та мовою.

Основні положення теорії фреймів висвітлені в наукових працях низки вчених: Е. Чарняка [1], Р. Шенка [12], М. Мінського [11], Т. А. ван Дейка [2], Е. Гофмана [7], Дж. Лакоффа [9], Ч. Філлмора [4; 5; 6], П. Гейєса [8], С. Жаботинської [13] й ін. Зокрема, праці Е. Чарняка - це унаочнення процесів, які відбуваються в штучному інтелекті. У них ідеться про розробку моделей представлення знань задля їх успішного практичного застосування в роботі 3 комп'ютером. Під фреймами дослідник розуміє інформацію, доступ до якої здійснюється через мовні тексти, створені шляхом відображення (запису) знань на папері, коли структура знань проявляється в процесі їх мовної реалізації. На думку вченого, першим кроком, що веде до впорядкування й організації нової інформації, $\epsilon$ «запис серії інструкцій, які повинні чітко пояснювати, що потрібно зробити для виконання завдання» [1, с. 356].

Важливе значення для лінгвістики має прагнення дослідників довести, що моделі знань i мислення, які застосовуються в роботі над штучним інтелектом, сприяють розумінню текстів природної мови. Одним із таких дослідників $є$ Д. Метцинг, котрий убачає головним завданням когнітивної лінгвістики розробку таких фреймових структур, які б забезпечили доступ лексичної семантики до ментального лексикону. Під фреймом учений розуміє «текст спеціального формату, створений на мові репрезентацій, що повинен моделювати знання, яким володіє людина» [10, с. 49].

У цьому дослідженні фрейми розглядаємо як когнітивні утворення, що мають своє дискурсивне втілення у фреймових структурах. Ключовими компонентами фреймових структур $\epsilon$ термінальні елементи, за допомогою яких відбувається мовна реалізація терміналів

(C) Козак C., 2020 
відповідних фреймів. Згідно 3 дефініцією, зафіксованою в словнику німецького видавництва «Duden», почуття - це внутрішнє поривання, відчуття людини, що визначають ії налаштованість та ставлення до світу (Gefühl ist seelische Regung, Empfindung des Menschen, die seine Einstellung und sein Verhältnis zur Umwelt mitbestimmt [3, c. 613]).

Методи та методика дослідження зумовлені метою й завданнями розвідки, своєрідністю іiі об'єкта, предмета та фактологічного матеріалу. У дослідженні застосовано лексикографічний метод, за допомогою якого визначено базові термінали фрейму «ПочуТТя» («GEFÜHL»): ‘ВНУТРІШНЕ ПОРИВАННЯ' ('SEELISCHE REGUNG'), ‘ВІДчУТTЯ’ ('EMPFINDUNG'), 'НАЛАШТОВАНІСТЬ' ('EINSTELLUNG'), 'СТАВЛЕНHЯ ДО СвITУ’ ('VERHÄLTNIS ZUR WELT'), а також описово-аналітичний метод для аналізу лексичних одиниць, що представляють термінали фрейму GEFÜHL у досліджуваному творі, й інтерпретативний контент-аналіз для визначення ролі зазначених фреймових структур у літературно-художньому дискурсі.

Результати та дискусії. Мета цієї статті - аналіз фреймових структур, що описують емоції та почуття персонажів у німецькомовному художньому дискурсі. Дослідження виконано на матеріалі роману «Ungeduld des Herzens» («Нетерпіння серця»), написаного австрійським письменником Стефаном Цвейгом, одним із видатних німецькомовних прозаїків минулого століття. У цьому творі автор змальовує Австро-Угорщину початку ХХ ст. напередодні Першої світової війни, описуючи побут та звичаї того часу. Роман рясніє найдрібнішими психологічними нюансами, у яких розкрито емоції й вчинки персонажів, про що свідчать численні фреймові структури на позначення людських почуттів.

Події у творі відбуваються в 1913 р. в невеликому місті неподалік Відня. Оповідь ведеться від особи головного героя - 25-річного лейтенанта кавалерії австрійської армії Антона Гофміллера. Військова служба вважалася надзвичайно престижною для чоловіка, однак одноманітне життя в гарнізоні маленького містечка та відсутність перспектив дуже швидко надокучили молодому офіцерові. Тож він без вагань приймає запрошення на званий вечір до замку найзаможнішого в окрузі землевласника - пана фон Кекешвальви. Тут Гофмілер знайомиться $з$ двома чарівними дівчатами - Едіт та ії кузиною Ілоною. Антон й Ілона швидко знаходять спільні теми для розмови, багато танцюють, словом, весело проводять час. I тут чоловікові спадає на думку, що він геть забув про Едіт, доньку господаря обійстя, і запрошує іiі на танець. У відповідь дівчина починає несамовито ридати.

Як бачимо, уже на початку твору можна простежити численні зовнішні та внутрішні лінгвістичні детермінанти людських стосунків, поглядів, думок, почуттів. Під час першої зустрічі головних героїв твору в будинку навіть повітря стає насиченим гаммою емоцій та почуттів. Антон, не знаючи, що Едіт не може ходити, завдає їй своїм запрошенням великих страждань. Дівчина, напевне, не раз мріяла про танець. I тепер вона у відчаї, адже не може здійснити те, чого їй завжди так хотілося. Приплив сорому та жаху наповнює все тіло молодої жінки. У цей момент їй важко стримати свої почуття: “Aber was jetzt geschieht, ist furchtbar. Der vorgebeugte Oberkörper fährt mit einem Ruck zurück, als wollte er einem Schlage ausweichen, <...> und nur die Augen starren unbeweglich auf mich mit einem solchen Ausdruck von Schrecken, wie er mir noch nie im Leben entgegengefahren ist. $<\ldots>$ aber trotzdem, sie flüchtet nicht weg, sie klammert sich nur noch verzweifelter an die schwere Tischplatte. Und immer wieder dieses Schüttern, dieses Zittern von den angekämpften Fäusten bis hinauf ins Haar. Und plötzlich bricht es heraus: ein Schluchzen, wild, elementar wie ein erstickter Schrei“" (S. Zweig, c. 27).

У наведеному вище уривку автор зображує відчай головної героїні роману - Едіт. Він відтворює іiі внутрішній стан, переживання через опис зовнішності: "der vorgebeugte Oberkörper", "die Augen starren unbeweglich". Фреймова структура насичена художніми засобами, що виразно підкреслюють емоції дівчини. Автор використовує порівняння “...der vorgebeugte Oberkörper fährt mit einem Ruck zurück, als wollte er einem Schlage ausweichen", "ein Schluchzen, wild, elementar wie ein erstickter Schrei“, - щоб показати несподіваність та раптовість дій Антона для Едіт, дочки господаря будинку, а також щоб передати біль, якого завдали їй ці слова.

Не менш яскраво передано емоції й почуття в наступному фрагменті. Стефан Цвейг створює певний контраст між внутрішнім станом Гофміллера та його оточенням у цей момент. У будинку шум і гамір, усі запрошені веселяться, проте Антону зовсім не до розваг, у його душі 
страх, що всі помітили його «ганебний» вчинок: "Ich stehe mit gewürgter Kehle, Übelkeit im Mund, an der Schwelle des Salons, der wirbelt und schwirrt und schwatzt mit seinen (mir plötzlich unerträglichen) unbefangen plaudernden, lachenden Menschen, und denke: fünf Minuten noch, und alle wissen von meiner Tölpelei. < ...> In diesem Augenblick sehe ich wie durch einen Nebel den Vater. Mit einem etwas bedrückten Gesicht - weiß er schon? - kommt er eben quer durch den Saal. Geht er am Ende auf mich zu? Nein - nur ihm jetzt nicht begegnen! Eine panische Angst packt mich plötzlich vor ihm und vor allen. Und ohne recht zu wissen, was ich tue, stolpere ich zur Tür, die hinausführt in die Hall, hinaus aus diesem höllischen Haus“" (S. Zweig, c. 29). Письменник передає тривогу та паніку Антона, використовуючи термінальні елементи, які, описуючи тілесні відчуття головного героя, відтворюють його внутрішній стан: "mit gewürgter Kehle", "Übelkeit im Mund", "panische Angst". За допомогою порівняння (“wie durch einen Nebel”) автор показує переживання цього персонажа, його страх після такої неприємної ситуації зустрітися з батьком Едіт - Кекешфальвою. Як бачимо, у наведеній фреймовій структурі ключовими $\epsilon$ термінальні елементи, пов'язані 3 відчуттями й емоціями. Доволі красномовним є вираз "eine panische Angst packt mich", за допомогою якого письменник відображає кульмінацію напруження та хвилювання молодого лейтенанта.

Незважаючи на страх перед господарем будинку, де трапилася неприємна для Антона Гофміллера подія, останній усе ж відчуває прихильність до старого Кекешфальви, котрий навіть після прикрого інциденту зберігає до нього своє привітне ставлення: "Ich konnte nicht gleich schlafen gehen an jenem Abend, ich war zu erregt. So winzig der Anlass sich auch, von außen gesehen, darstellen mochte - es war doch schließlich nichts Weiteres geschehen, als dass ein alter Mann mir zärtlich den Ärmel gestreichelt hatte - diese eine verhaltene Geste inbrünstigen Danks hatte schon ausgereicht, um ein Innerlichstes in mir zum Fluten und Überfluten zu bringen. Ich hatte in dieser überwältigenden Berührung eine Zärtlichkeit von so keuscher und doch leidenschaftlicher Innigkeit erfahren, wie nicht einmal von einer Frau" (S. Zweig, c. 59). У наведеному фрагменті ключовими $\epsilon$ термінальні елементи "erregt", "zärtlich", "inbrünstigen Danks", "ein Innerlichste", "leidenschaftliche Innigkeit”. Головний герой відчуває приплив емоцій, викликаних поводженням заможного чоловіка. Він надзвичайно вражений тим, що Кекешфальва 3 такою ніжністю й доброзичливістю поставився до нього (“ein alter Mann mir zärtlich den Ärmel gestreichelt hatte"), $\mathrm{i}$ це наповнило серце Антона чимось справді величним, чого він, мабуть, раніше ніколи не відчував ("um ein Innerlichstes in mir zum Fluten und Überfluten zu bringen").

Молодий офіцер, який виріс у багатодітній сім'ї і який відчував брак батьківської ласки й любові, не усвідомлював, що допомога людям може приносити радість. Він уперше у своєму житті відчув гордість від того, що міг допомогти іншим, адже саме завдяки йому старий Кекешфальва міг бачити посмішку своєї єдиної доньки Едіт: "Zum ersten mal in meinem Leben war mir jungem Menschen Gewissheit geworden, irgend jemandem auf Erden geholfen zu haben, und maßlos war mein Staunen, dass ich kleiner, mittelmäßiger, unsicherer Offizier wirklich Macht haben sollte, jemanden derart glücklich zu machen" (S. Zweig, c. 59).

Відчуття, що переповнюють лейтенанта, яскраво передано в наступних фреймових структурах: "Ich gehe so rasch in meiner Erregung durch die dunklen Gassen, dass mir ganz warm wird. Am liebsten möchte ich den Rock aufreißen, so dehnt sich mir das Herz. Denn in dieser Überraschung drängt und enthüllt sich unvermutet eine neue, eine zweite, die noch berauschender wirkt - nämlich, dass es so leicht war, so rasend leicht, diese fremden Menschen zu Freunden zu gewinne" (S. Zweig, c. 61). Як бачимо, лексичні одиниці “Erregung”, "Überraschung”, "wird ganz warm", "dehnt sich das Herz", що є в цьому фрагменті ключовими термінальними елементами опису внутрішнього стану героя, використані автором твору, щоб зобразити Антона Гофміллера як особу, яка вперше відчула радість від усвідомлення своєї неперевершеності та вміння завойовувати серця людей, котрі його оточують.

Головним оповідачем подій, а також своїх внутрішніх переживань $\epsilon$, як бачимо, головний персонаж твору - Антон Гофміллер. Саме він розповідає про прихильність до нього Ілони, кузини Едіт, і неможливість протистояти іiі принадам і проявам іiі симпатії до нього: “Zuerst freilich - ich gestehe es willig ein - hatten die küsslich vollen Lippen, die fülligen Arme Ilonas, die magyarische Sinnlichkeit, die sich in ihren weichen, schwingenden Bewegungen verriet, mich jungen 
Menschen auf die angenehmste Art irritiert" (S. Zweig, c. 64). Незважаючи на спроби дівчини спокусити молодого лейтенанта, йому все-таки вдається ціною неймовірних зусиль зберігати холодне серце та не піддаватись емоціям. Зрозуміти це читачеві допомагають ключові компоненти фреймових структур: "Ich musste einigemal meine Hände in straffer Dressur halten gegen das Verlangen, einmal dies warme, weiche Ding mit den schwarzen, lachenden Augen an mich heranzureißen und ausgiebigst abzuküssen" (S. Zweig, c. 64).

Причина, через яку Антон Гофміллер не міг повною мірою проявити свою симпатію Ілони до кузини Едіт описує наступна фреймова структура: "Ich bin nicht sehr zufrieden mit mir. Warum diese merkwürdige Eile Ilonas, diese Geniertheit, als fürchte sie sich, mit mir gesehen zu werden, und wozu dieses hitzige Losfahren?" (S. Zweig, c. 80). Термінальні елементи "diese merkwürdige Eile", "Geniertheit", "dieses hitzige Losfahren" демонструють небажання дівчини залишатися в товаристві молодого офіцера, викликане страхом бути поміченою іншими людьми.

Зі свого боку, Гофміллер розмірковує над своєю поведінкою стосовно сім'ї Кекешфальви: "Und dann: wenigstens einen Gruß hätte ich höflicherweise mitschicken sollen an den Vater, irgendein nettes Wort an Edith, sie haben mir doch nichts getan! Aber anderseits bin ich auch zufrieden mit meiner reservierten Haltung. Ich habe standgehalten. Jetzt können sie wenigstens von mir nicht denken, dass ich mich ihnen aufdrängen will" (S. Zweig, c. 85). Як бачимо, герой не поспішає демонструвати прихильність до родини Едіт, щоб не виказати своєї надмірної зацікавленості: “dass ich mich ihnen aufdrängen will”. 3 огляду на це, чоловік намагається бути більш стриманим у ставленні до Кекешфальви, про що свідчать термінальні елементи "standgehalten", "zufrieden mit meiner reservierten Haltung".

Емоції та почуття можуть бути виражені також за допомогою термінальних елементів, що описують зовнішній вигляд персонажів твору, свідченням чого - така фреймова структура: "Ihr Blick, grau, streng und scharf, weicht nicht von mir. Je umständlicher ich schwätze, um so argwöhnischer spitzt er sich zu. Ich sehe, wie die Finger an der Lehne auf und nieder zucken" (S. Zweig, с. 89). Через зображення погляду Едіт, сірого (grau), суворого (streng), різкого (scharf), Стефан Цвейг показує весь коловорот емоцій, які переживає молода дівчина.

Героїня твору не приховує своїх почуттів до Антона Гофміллера. Вона відверто виказує їх, «виливаючи» на нього в розмові весь свій біль і жаль від усвідомлення того, що близькі до неї люди змушені обманювати іiі, аби не завдавати дівчині нових страждань через іiі, як вона вважає, недолугість, викликану хворобою: “Keine neuen Erfindungen jetzt... nur keine neuen Unwahrheiten, ich ertrag keine mehr! Mit Lügen bin ich überfüttert bis zum Erbrechen. Von früh bis abends löffelt man sie mir ein: >Wie gut du heute aussiehst, wie famos du heute marschierst... großartig, es geht schon viel, viel besser - immer dieselben Beruhigungspillen von früh bis abends, und keiner merkt, dass ich daran ersticke. Warum sagen Sie nicht kerzengrad: Ich habe gestern keine Zeit, keine Lust gehabt. $<\ldots>$ Ich bin nicht so dumm, wie ihr alle meint, und kann schon einen guten Brocken Aufrichtigkeit vertragen" (S. Zweig, c. 90). За допомогою термінальних елементів "Unwahrheiten ertrag keine mehr", "mit Lügen bin ich überfüttert bis zum Erbrechen" письменник передає розпач дівчини, млосну гіркоту від нещирих компліментів друзів і знайомих. Злість та відчай керує Едіт. Вона не в змозі більше стримувати себе, що, зокрема, яскраво демонструє наступна фреймова структура: "Nur eins ist mir widerlich und eins ertrag ich nicht: Ausreden und Schwindel und Lügereien - damit bin ich eingedeckt bis an den Hals" (S. Zweig, c. 90). Едіт не потрібні панегірики від друзів (“Beruhigungspillen von früh bis abends"), та й самі друзі ій не потрібні, якщо вони здатні лише на жалощі, у той час як дівчина так прагне рівноцінних, щирих стосунків. Їй, як повітря, потрібні правда, відверте ставлення (“kann schon einen guten Brocken Aufrichtigkeit vertragen"), адже вона втомилася від постійних відмовок (“Ausreden”), обману (“Schwindel”) та брехні (“Lügereien”).

Твір насичений фреймовими структурами, що описують негативні відчуття персонажів, зображуючи подекуди цілий спектр емоцій героїв, пов'язаних із їхнім внутрішнім занепокоєнням, викликаним поведінкою Едіт, яка, закохавшись у молодого офіцера, утратила спокій і постійно перебуває в пригніченому стані. Сам Антон Гофміллер не готовий брати відповідальність за ці стосунки, вважаючи їх лише примхою Едіт. Його більше хвилює думка навколишніх (“...so steht er mit gesenkten Augen beunruhigt herum”), а надто самого Кекешфальви: "Dann entsteht ein merkwürdiges Schweigen. Alle spüren ja alles von allen in diesem Haus; zweifellos 
muss der alte Mann gefühlt haben, dass eben eine gefährliche Spannung zwischen uns beiden schwingt" (S. Zweig, с. 93). Термінальні елементи "merkwürdiges Schweigen", "alle spüren alles" та "eine gefährliche Spannung schwingt" у наведеній фреймовій структурі описують збентеження людей, які так чи інакше причетні до цієї любовної історії. Адже кожен усвідомлює приреченість таких стосунків, коли одна зі сторін сповнена палкого кохання, а інша демонструє лише жаль та співчуття.

Висновки. У результаті проведеного дослідження виявлено, що структурними компонентами фрейму «Почуття» («Gefühl») є термінали 'Внутрішнє поривання' ('seelische Regung'), 'Відчуття' ('Empfindung'), 'Налаштованість' ('Einstellung'), 'Ставлення до світу' ('Verhältnis zur Welt'). Аналіз текстового матеріалу засвідчив, що фреймові структури на позначення емоцій і почуттів є продуктивним засобом у відображенні внутрішнього світу літературних героїв й ефективним механізмом експлікації авторської прагматики в художньому дискурсі. Важлива роль фреймових структур полягає в тому, що вони дають ключ до розуміння вчинків персонажів твору та їхніх мотивів, відображають почуття, які штовхають дійових осіб на відчайдушні кроки - на подвиги й злочини, висвітлюють пристрасті, що можуть стати як причиною невдач, так і підгрунтям для зародження нових стосунків.

Перспективою подальших наукових розвідок може стати дослідження фреймових структур, що описують не лише почуття та емоції, а й міжособистісні стосунки літературних героїв у художньому дискурсі.

\section{References}

1. Charniak, E. 1977. "A Framed Painting: The Representation of a Common Sense Knowledge Fragment". Cognitive Science 1: 355-394.

2. Dijk, T. A. van. 1977. "Semantic Macrostructures and Knowledge Frames in Discourse Comprehension". Cognitive Processes in Comprehension, edited by M. A. Just, P. A. Carpenter, 3-32, Hillsdale.

3. Duden. 2001. Deutsches Universalwörterbuch. Mannheim, Leipzig, Wien, Zürich: Dudenverlag.

4. Fillmore, Ch. J. 1987. "A Private History of the Concept 'Frame”". Concepts of Case. Tübingen, 28-36.

5. Fillmore, Ch. J. 1986. "U”-Semantics, Second Round”. Quaderni di Semantica VII: 49-58.

6. Fillmore, J. 2003. Ch. Form and Meaning in Language: Papers on Semantic Roles. Stanford : CSLI Publications.

7. Goffman, E. 1974. Frame Analysis. An essay on the organization of experience. N.Y.

8. Hayes, P. 1980. "The Logic of Frames". Frame Conceptions and Text Understanding 46-67.

9. Lakoff, G. 1987. Women, Fire and Dangerous Things: What Categories Reveal about the Mind. Chicago: University of Chicago Press.

10. Metzing, D. 1981. "Frame Representations and Lexical Semantics". Words, Worlds, and Contexts. Berlin, $320-342$.

11. Minsky, M. 1981. "A Framework for Representing Knowledge [Gekürzte und leicht veränderte Fassung von Minsky]”. Mind Design. Cambridge, 95-128.

12. Schank, R. C., Abelson, R. P. 1977. Scripts, Plans, Goals, and Understanding. Hillsdale.

13. Zhabotinskaya, S. 2009. "Modeli representatsii znaniy v kontexte razlichnykh shkol kognitivnoy lingvistiki: integrativnyy podhod". Visnyk Kharkivskoho Natsionalnogo Universytetu (848): 3-9.

14. Zweig, S. 1954. Ungeduld des Herzens. Frankfurt a. M.

Козак София. Фрейм «ЧУВСТВО» в художественном дискурсе (на материале творчества австрийского писателя С. Цвейга). В статье анализируются фреймовые структуры на обозначение чувств в художественном дискурсе. Подробно рассматриваются понятия «фрейм» и «фреймовая структура». Фреймы квалифицируются как когнитивные образования, составными частями которых являются терминалы и которые реализуются в дискурсе посредством фреймовых структур. Ключевыми компонентами фреймовых структур являются терминальные элементы, непосредственно связанные с языковой реализацией терминалов. Исследование проводилось на материале романа Стефана Цвейга «Ungeduld des Herzens» («Нетерпение сердца»). В указанном произведении анализируются фреймовые структуры, в которых терминальные элементы, представляющие фрейм «Чувство», отражают эмоциональную сферу персонажей и раскрывают их внутренний мир. В исследовании описывается структура фрейма «Чувство» и определяются его главные терминалы. Этот фрейм рассматривается как ментальное образование, в основе которого - категориальные знания о человеческих чувствах - то, что люди ощущают не разумом, а внутренне, «в душе», например страх, облегчение, радость, беспечность, неуверенность и др. На основании словарной дефиниции определяются базовые терминалы фрейма «ЧуВСТВО» («GEFÜHL»): «Внутренний порыв» («seelische Regung»), «Ощущение» («Empfindung»), «Настроенность» («Einstellung»), «Отношение к миру» («Haltung zur Welt»). В рамках указанных терминалов проводится комплексный анализ лексических единиц, изображающих чувства литературных героев романа «Ungeduld des Herzens», показываются разные оттенки их переживаний и мыслей, описываются сокровенные мечты, представляются различные порывы человеческой души. Фреймовые структуры, которые анализируются, дают ключ к пониманию поступков героев произведения и их 
мотивов, изображают чувства, которые толкают действующих лиц на отчаянные шаги, как на подвиги, так и на преступления, описывают страсти, ставшие причиной неудач или же основанием для зарождения новых отношений. Анализ текстового материала показал, что фреймовые структуры на обозначение эмоций и чувств являются эффективным средством в изображении внутреннего мира литературных героев, а также действенным механизмом экспликации авторской прагматики.

Ключевые слова: фрейм, фреймовая структура, терминал, терминальный элемент, чувство, эмоция.

Kozak Sofiia. Frame "Feeling" in Fictional Discourse (on the material of the literary work of the Austrian writer S. Zweig). The article deals with the analysis of the frame structures denoting feelings in the literary discourse. The notions "frame" and "frame structure" have been viewed from different angles. Frames are qualified as cognitive formations, the component parts of which are the terminals and which are being realized in the discourse by means of the frame structures. The key constituents of the frame structures are the terminal elements which are directly related to the language realization of the terminals. The research has been carried out on the material of Stefan Zweig's novel «Ungeduld des Herzens» («Beware of Pity», literally: «The Heart's Impatience»)). In this literary work the frame structures have been analyzed, in which the terminal elements representing the frame "Feeling" portray personages' emotional sphere and disclose their inner world. In the present research the structure of the frame "Feeling" has been described and its main terminals have been defined. This frame is considered as a mental formation based on the categorial knowledge of human feelings - the fact that people sense not with the mind but inwardly, "in the heart", for instance fear, relief, joy, unconcern, uncertainty etc. On the basis of the dictionary definition the basic terminals of the frame «FEELING» («GEFÜHL») were determined: «Internal Aspiration» («seelische Regung»), «Sensation» («Empfindung»), «Mood» («Einstellung»), «Attitude to the World» («Haltung zur Welt»). Within the framework of the stated terminals the complex analysis of the lexical units denoting feelings of the literary characters of the novel "Ungeduld des Herzens" has been carried out, different nuances of their emotional experience and thoughts have been shown, the innermost dreams have been revealed and the most thinkable aspirations of human soul have been depicted. The analyzed frame structures give a key to understanding of heroes' behavior and their motives, represent their feelings that incite them to reckless acts, both to feats and to evil deeds, portray passions which can become the cause of a failure as well as the basis for the beginning of the new relationships. The analysis of the text material has shown that the frame structures denoting emotions and feelings are an effective means in the representation of the inner world of the literary heroes as well as an efficient mechanism of the explication of the author's pragmatics.

Key words: frame, frame structures, terminal, terminal element, feeling, emotion.

DOI: https://doi.org/10.32782/2410-0927-2020-13-11

УДК $811.111^{\prime} 42:[316.7: 316.658]: 177.1$

Еліна Коляда, Анастасія Шнайдер

\section{РЕАЛІЗАЦІЯ КОМУНІКАТИВНИХ СТРАТЕГІЙ НЕГАТИВНОЇ ВВІЧЛИВОСТІ В БРИТАНСЬКОМУ Й АМЕРИКАНСЬКОМУ ПОЛІТИЧНОМУ ДИСКУРСІ}

У статті досліджено особливості реалізації комунікативних стратегій і тактик негативної ввічливості в сучасному британському й американському політичному дискурсі. Негативна ввічливість являє собою детально розроблений набір комунікативних стратегій, спрямованих на демонстрацію визнання незалежності співрозмовника. Негативну ввічливість вважають основою шанобливої поведінки.

Увага до обраної теми зумовлена тим, що ввічливість є невід’ємним елементом мовлення політичних діячів, що сприяє формуванню соціального іміджу політика. Стратегії й тактики негативної ввічливості є ефективними інструментами для регулювання процесів комунікації. Вони сприяють уникненню конфліктів, розвитку та підтримці гармонійних відносин між комунікативними партнерами. Матеріалом дослідження слугували тексти промов експрезидента США Дональда Трампа й колишньої прем'єр-міністра Великої Британії Терези Мей.

Проаналізовано особливості реалізації трьох найбільш уживаних у рамках політичного дискурсу комунікативних стратегій негативної ввічливості: стратегії ухилення, стратегії вибачення та стратегії апелювання до норми. Комунікативні стратегії негативної ввічливості спрямовані на 1) дистанціювання співрозмовників, 2) демонстрацію визнання адресантом незалежності й особистісної автономії адресата, 3) переконання адресата у відсутності наміру в адресанта порушити його особистісні кордони, 4) мінімізацію тиску на адресата з боку адресанта.

Стратегія ухилення реалізується за допомогою тактики обмеження власною оцінкою, тактики перепитування й тактики пом'якшення категоричності висловлення. Стратегія вибачення актуалізується тактикою визнання завданої шкоди та тактикою визнання небажання зашкодити. Стратегію апелювання до норми реалізовує тактика демонстрації загальноприйнятих правил і вимог, що регулюють поведінку членів соціуму. Виявлено, що Тереза Мей надає перевагу офіційно-діловому стилю мовлення, у той час як Дональд Трамп більше тяжіє до неформального стилю мовлення, що зумовлено низкою культурних, соціальних і ситуативних чинників.

Ключові слова: негативна ввічливість, комунікативна стратегія, комунікативна тактика, адресант, адресат, політичний дискурс.

(C) Коляда Е., Шнайдер А., 2020 